をこ元たすのもあるが，標準波で $440 \mathrm{kV}$ 印加時はス トリーマは平均として 1.4E。 等露界線までしか到遟

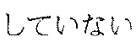

以上の説明より明ら加のように，第 1 種ストリーマ

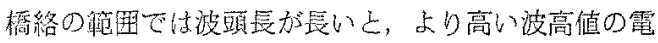
压でなりればストりーマ怔電翟くら点をこ光ることが できず，破烄にならない。したがって，波顛長が長け れば 50\%フラッシオーバ電圧が高くなる。しかし， $50 \%$ フラッシオーバ電压の上暑は第2 程ストリーマ 橋絡が常に起こる值で飽和する。

\section{7. むすび}

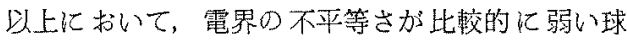
ギャップにおける鱼極性街整電压によるフラッシオー バの珄成過程について考察を行ない，いままで多分に

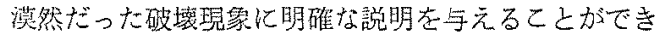
た。しれら老裂約すると，

（1）陽極向けストリーマ発生のための初期電子は 常に存在し，陰極より婯界放射された委のである。 フラッシオーバを決定するのは陽極向けストリーマの 電極橋絡，言い營えれば，電界分布のくら点圭こえら れるか否かにある。

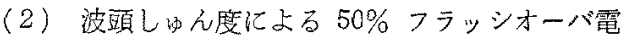
圧変北の原因は，ストリーマ進展に及畦電王立上り

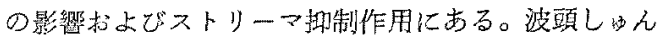
度が大きけ扎ば，ストリーマが電界のくら点に到達す る時到での電極間電生がより大きい值になりうるの

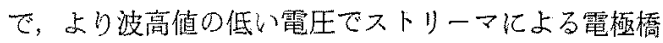
絡が起こり、フラッシオーバてなる。

終わりに，本舁䠝装固の設置にご尽力いただいた本

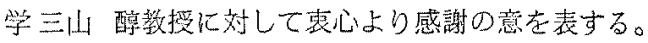
また，実験に協力した本学学生竹下㻎雄君（現在，東

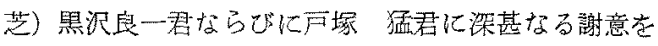
表する次第で岕る。

(昭和 47 年 3 月 29 日受付, 闰 47 年 6 月 16 日再受付)

\section{文献}

(1) H. Baatz: CIGRE-Ber. No. 325 (1962)

(2) K. Berger: CIGRE-Ber. No. 326 (1956)

(3) K. Feser: Flektrotech. Z. (FTZ)-A 91, 6, 321 (1970)

(4) K. Berger, et al.: Bull. SEV 56, 1, 2 (1965)

(5) J. Wiesinger: Bull. SEV 57, 6, 243 (1966)

(6) J. Wiesinger: Bull. SEV 58, 3, 113 (1967)

(7) J. Wiesinger: Elektrotech. Z. (ETZ)-A 90, 17, 407(1969)

(8) W. Lampe: Arch. Elektrotech, 47, 6, 338 (1963)

(9) J.L. Pack, et al.: J. Chern. Phys. 44, 5, 1870 (1966)

(10) F. Llewelly-Jones: Proc. Roy. Soc. A 218, 88 (1953)

(11) E. Nasser, et al.: J. Appl. Phys, 39, 4, 3707 (1968)

(12) 伊传：雷学誌 91,1730 (昭 46-9)

(13) S.C. Brown: Basic Data of Plasma Physics (1966) The MIT Press.

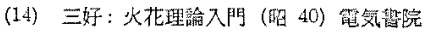

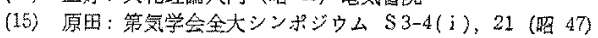

\title{
正誤
}

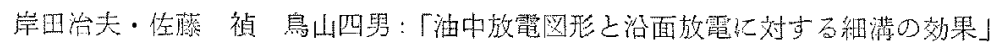

(Vol. 92-A, No. 5, May, 1972, p. 246 揭践)

UDC 脱落

UDC $621.3 .015 .533: 537.528$

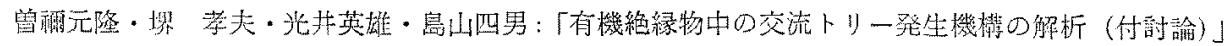
(Vol. 92-A, No. 8, Aug., 1972, p. 374 揭载

\begin{tabular}{|c|c|c|c|c|c|c|c|c|c|}
\hline$\therefore-$ & 行 & \multicolumn{4}{|c|}{ 誤 } & \multicolumn{4}{|c|}{ 正 } \\
\hline 374 ヘーシ & 著者氏名 & 岛 & $山$ & 四 & 男 & 鳥 & 山 & 四 & 男 \\
\hline
\end{tabular}

